\title{
The Effort to Decrease Maternal and Child Mortality Rates through Cultural Transformation
}

\author{
Atik Triratnawati ${ }^{1}$, Rani Ditya Kristianti ${ }^{2}$, Aldo Pandega Putra ${ }^{3}$, Pandu Bagas Setyaji ${ }^{4}$ \\ ${ }_{1,2,3,4}$ Dept. of Anthropology, Faculty of Cultural Sciences, Universitas Gadjah Mada, Yogyakarta, Indonesia
}

\begin{tabular}{l}
\hline \hline Article Info \\
\hline Article history: \\
Received Nov 26, 2015 \\
Revised Dec 22, 2015 \\
Accepted Feb 26, 2016 \\
\hline
\end{tabular}

\section{Keyword:}

Cultural transformation

Ende

Massage

Maternal and infant

Mortality

Nutrition

\begin{abstract}
Maternal and infant mortality in Ende is still high, but research related a social science is rare. The cultural aspect and medical factors such as the lack of primary health care services are also play a role. This study aims are to identifying and formulate the local cultural transformation as a way to solve maternal and infant mortality. This ethnographic research was conducted in 2013. The study carried not only interviews, but also observation towards reproductive-age women, heads of family, traditional birth attendants, doctors, midwives, local leaders, traditional leaders, pastors and sisters, local government officials, and head of health district at Ende. Data is analyzed phenomenologically. The strong belief to local wisdom and local tradition has implication to people's attitude towards traditional birth attendants. Traditional birth attendants hold superior position in the community. They also have strong influence due to their ability to massage, correctly guess infant's sex, reposition infant in the womb, and stop bleeding during labor. Maternal and/or infant mortality has nothing to do with traditional birth attendants because local people believe that such case happens as a result of hex or black magic called ru'u. Anemia, bleeding, food taboo, and incorrect diet pattern worsen the overall condition of pregnant women. Cultural transformation is done by alternating TBAs practices in massaging pregnant women. TBAs are encouraged to massage pregnant women's back instead of stomach since pregnant women often have to deal with low back pain during pregnancy.
\end{abstract}

Copyright () 2016 Institute of Advanced Engineering and Science. All rights reserved.

\section{Corresponding Author:}

Atik Triratnawati,

Dept. of Anthropology, Faculty of Cultural Sciences,

Universitas Gadjah Mada, Yogyakarta, Indonesia,

Sosio Humaniora 1, Bulaksumur, Sleman, D.I. Yogyakarta.

Email: atik_triratnawati@yahoo.co.id

\section{INTRODUCTION}

Maternal and infant mortality is still one of the main public health problems in Indonesia, including in East Nusa Tenggara (ENT). Total fertility rate in ENT of 4.2 is the highest in Indonesia, while infant mortality rate in every 1000 birth is 57 - second in the country after West Nusa Tenggara [1], [2]. Both local and central government have attempted various ways to decrease this maternal and infant mortality rate with no significant impact.

Since 2009, the local government has implemented a program called Revolution of Maternal and Infant Health with its jargon: "if one person comes, two or more persons return. It is not acceptable if only one person return." This illustrates the importance of going back from giving birth with one or two babies (twin), and avoiding the death of either mother or child or even both. In this program, it is not acceptable to have dukun bayi (Traditional Birth Attendants) helping the birthing process. Every pregnant woman must only go to health facilities such as Primary Health Care Centre (Puskesmas) or clinic [3]. However, the implementation of this program is challenged by the limited number of health personal such as specialist. In 
order to decrease maternal and infant mortality rates, the local government collaborated with Australian Agency for International Development (AUSAID) in 2010 with their joint program called "clinical contracting out" or sister hospital in 6 regional hospitals in the province with 6 hospital or Medical Faculty partners from outside the region [4]. By placing specialist in six regional hospitals in East Nusa Tenggara, maternal and infant mortality rate can be reduced.

Table 1. Cases of Intra Uterine Fetal Demise (IUFD) Program Sister Hospital in 6 Regional Hospitals

\begin{tabular}{cccc} 
& in East Nusa Tenggara, 2010-2011 & \\
\hline RSUD (Regional & Pre Sister & Sister Hospital 1 & Sister Hospital 2 \\
Hospital) & Hospital & (June 2010-May 2011) & (June 2011- present) \\
\hline Larantuka & 27 & 8 & 15 \\
Soe & 22 & 26 & 10 \\
Lembata & 4 & 7 & 12 \\
Waikabubak & 10 & 22 & 14 \\
Ende & 33 & 33 & 26 \\
Bajawa & 20 & 0 & 12 \\
\hline
\end{tabular}

Source: Sister Hospital in ENT 2010-11

Findings from current population survey releases in 2005 "Survei Penduduk antar Sensus 2005" [5] in East Nusa Tenggara revealed that in Ende, the average of surviving infants per woman is 2.739 (urban) and 2.907 (rural). On the other hand, married women or widowed has an average of 2.585 (urban) and 2.642 (rural) surviving infants [6]. The results show that married women or widowed with experiences of giving birth have ever had their infants died on an average rate of 0.15 (urban) and 0.27 (rural). Infant mortality in both hospitals and local community is no longer considered uncommon in Ende in particular, and in East Nusa Tenggara in general.

Qualitative monitoring and evaluation team of Sister Hospital Program from Universitas Gadjah Mada has conducted a study of health-related local practices in East Nusa Tenggara. The study found that women are commonly engaged in several customs and local practices related to pregnancy. From various practices that women in East Nusa Tenggara commonly do during the first trimester pregnancy period, one can actually bring harm to their health. During the first three months of their pregnancy, many women feel uncomfortable with their body. They believe that this is mostly related to their uterus being in a position it should not be. When this happens, women usually visit the traditional birth attendants (TBAs) to give them massage. TBAs are the first helper for such condition as they are considered the only persons who could heal pregnant women's problem. TBAs are considered the only ones able to return the condition of uterus.

Some cases of Intra Uterine Fetal Demise (IUFD) presented in Table 1. The massage practiced by TBAs often cause IUFD in East Nusa Tenggara. A doctor who has been working for more than 20 years in one regional hospital in Ende and a gynecologist who has been working for over 32 years in several districts in East Nusa Tenggara also stated similarly that TBAs usually massage women's belly in order to fix uterus's position. TBAs usually massage as if they are repositioning uterus like when fetus is still very young. This practice is estimated to have caused IUFD cases among pregnant women in East Nusa Tenggara. In addition, diet pattern and food taboo during pregnancy as well as the strong trust to TBAs contribute to the high rate of infant mortality. Maternal and infant mortality is also seen as something common for local people. Thus, it is perhaps not surprising that infant mortality is still high.

Pregnancy often triggers conflicts related to the female's body [7]. Woman feels weak and powerless, hence massage is considered to be a solution to re-energize. Massage tradition is known almost in every corner of Indonesia both as health treatment as well as for curing. Massage is a work based on art, while art is based on talent, willingness, objective, and collectivity. There are over 22 ways of massaging in massaging theory [8]. TBAs practice this tradition based on a knowledge passed from generation to generation. Massage can actually be advantageous to return the balance of macro cosmos and micro cosmos. In keeping such balance, dynamic and dialectic balance should be constructed in order to gain a homeostatic level [9]. However, it is important to practice massage in an appropriate manner. Massage should always follow particular procedure including which parts of human body are allowed to be massage and which are not. For stomach in particular, there are specific ways to massage because stomach is one of the body parts that should only be pressed gently [8]. TBAs in East Nusa Tenggara practice traditional massage for pregnant women without attending to massaging theory. They tend to pay no attention to which body parts that should be treated with care in massaging. Thus, medical practitioners often blame traditional massage because they consider massage as the cause of swelling [10]. This is very unfortunate as collaborative work between medical practitioners and traditional healers can attract patients in general. Respecting patients' belief 
system, including their belief in traditional healers should be done by health authorities [11]. Such beliefs have long been practiced by the community; hence making people perceive them as the truth.

In medical study, including Medical Anthropology, a traditional curing method can only be continued if it has positive impact for public health. On the other hand, if such method brings only harms, it must not be done [12]. Massage practiced to pregnant women on their early months is dangerous because the high IUFD cases are in fact driven by such practices. Nonetheless, stopping such traditional practice is not an easy task. There needs to be a cultural approach in order to change these local practices.

Traditional practice in pregnant women's health is part of local wisdom. Local wisdom can be understood as traditional knowledge or set of knowledge and practices used to solve problems or difficulties in an appropriate manner [13]. People of East Nusa Tenggara base their lives on social collective thinking, harmonious, and mystical, magical, and superstitious way of life. They also emphasize on symbolism, morality, and religiosity [14]. Local wisdom can be transformed into positive cultural strength through cultural transformation of local cultural symbols.

In developing countries, the socio cultural aspect of pregnancy and delivery practices is still exist, such as India especially in Andhra Pradesh revealed that not less than $80 \%$ of total child births are handled by TBAs in these tribal communities. The TBA's render different services for fulfilled of their social obligation rather than for economic gain. Their services are not strictly limited to the conduct of delivery. They also advice on different sex related problems and infertility. Social status of the TBAs are still high [15],[16].

In other country such as South Africa, the role of the TBAs is important. The Xhosa speaking women follow indigenous healing practice for both themselves and their babies because of the need to strengthen the womb against sorcery, to prevent childhood illness, and to treat symptoms they perceive that biomedical services would not be able to treat. Many of women agreed, that the period of pregnancy is a delicate time when women have lots of problems, some of which are particularly unpredictable and could lead to the death of the mother or child [17]. Similar to India and Africa, in Dhaka, Bangladesh, 70\% of women in urban areas give birth at home with non-medically trained providers. Women with deliveries at home were significantly more likely to report traditional practices to remove placenta than women who gave birth at health facilities [18].

The research question of the study is why in the area study the maternal and infant mortality high and how to understand and promote local culture/knowledge as an effort to decrease maternal and infant mortality rate?

\section{RESEARCH METHOD}

This ethnographic research is conducted in Detusoko Village, Detusoko District, Ende Regency, East Nusa Tenggara. This location is chosen because local people still strongly believe in local customs, particularly with regards to common practices during pregnancy. This village is also selected due to its relatively high incident of maternal and infant mortality as a result of certain practices during pregnancy and labor. Data collection was carried out from June-September 2013. The study team lived in the village in order to better observe and interact with the informants. Observation was conducted towards pregnant women, mothers with toddlers, family who had experiences of maternal and infant mortality, TBAs, and health workers in primary health centers. In-depth interviews were done with approximately 75 people from various backgrounds like those being observed. Several key informants were selected for their abundant knowledge in those four research topics.

The data from the field was interpret using phenomenology approach which is similar the emic point of view to the community [19]. Data result of the observation and in-depth interview was cleaned, categorized and analyzed into several subtopics which is also indicate of several barrier factors influenced in the maternal and infant mortality such as: tradition of massage during pregnancy; belief and myths related pregnancy; the role of the TBA's; decision making process; food taboo among pregnant women; the meaning of maternal and infant mortality; effort to decrease maternal and infant mortality using socio-cultural transformation.

\section{RESULTS AND ANALYSIS}

The Detusoko is the only special village in Detusoko District which consists of 1 special village and 20 villages. There are approximately 1,168 people in this village - most of whom are from Lio ethnic group. There is a strong sense of local belief and custom among the people. People still maintain the belief of prinsip tiga tungku (3 fireplace principles) where government, religious leaders and traditional/leaders are of equal position. This belief has been translated into most aspects of local lives, including health-related 
practices. Economically, people of Detusoko largely work in agricultural sector as farmers (95\% of total population). Women are, thus, expected to work in the farms in order to provide for the family. Although Detusoko acts as Ende's granary, rice intended for the poor program (raskin) recipients are still considerably high. There are 87 households as raskin recipients from a total of 383 households in Detusoko. Because of high consumption of rice, they make use of raskin in addition to the rice they harvest from their lands. As an example, a family with three children usually needs around 2 kilograms of rice every day. The harvested rice from one's farms is not only used for daily consumption, but also to pay back their rice debts to their neighbors. This usually occurs if there is death ceremony or other traditional ceremony.

\subsection{Massage During Pregnancy: A Tradition}

There are two different kinds of massaging: pijat and urut. Pijat means getting massaged all over the body, while urut means only getting massaged on certain parts of the body. The benefit of getting urut is not only feeling relaxed, but also getting fixed with whichever parts of the body that previously felt stiff and uncomfortable. In addition, women also think that getting urut by TBAs can help repositioning infant inside the womb. A 47-year old university graduate female who works as a primary school teacher testified to this such as the following:

“Though now I live in Ende, and only occasionally return to Detusoko, I've always go to Detusoko to get urut during my five pregnancies. I drive a motorcycle daily, so I feel the baby went into a wrong position. Whenever I go to Grandma N, a neighbor in Detusoko, I feel my body gets normal again. I don't feel pain any longer. My mom always says to me that pregnant women should get urut routinely. And I do feel the benefits of it".

Interviews with head of Detusoko primary health center and midwives' clinics revealed which women visit TBAs for massage. Difficult childbirth cases in the primary health center are also generally related to how these mothers have often come to TBAs to get massage during their pregnancies. Doctors and health workers in primary health center usually come to this conclusion because, despite not having the mothers confessing to getting massaged in TBAs, the condition of the newly born babies confirms that the mothers visit TBAs. The PHC has put a ban on going to TBAs for pregnant women to get massaged. However, cases of babies born with bruised bodies show that the ban is overlooked. Once, there was even a case of an infant with a mark of TBA's hand. This only confirms that TBAs pressed the mother's stomach too hard.

The head of Detusoko primary health center said that massaging pattern of TBAs is not merely rubbing the stomach, but also doing motion as if making a bread. Although the custom of pregnant woman in Detusoko is not getting massaged as in what pijat has been explained previously, but only getting urut. Thus, they do not get massaged all over their body as in pijat, but only on certain parts of their body such as stomach. However, this practice has been proven harmful medically since most twisted cord among infants are found amongst those women who often visit TBAs to get urut.

On the other hand, this study reveals through interviews with pregnant women or those who had ever been pregnant before that these women tend to feel worried when asked to leave this practice. In general, they are worried to disobey pregnancy-related tradition. Pregnant women and urut are associated together. Like a coin with two faces, they cannot be separated. By not doing such local practices, pregnant women feel worried and fear of not giving birth smoothly.

\subsection{Getting hexed (ru'u)}

The role of tradition in pregnancy-related practices is relatively strong. It is already internalized in the mental map of pregnant women and local people in general in Detusoko; hence making them feel guilty or sinned if not doing it. Advices from parents, particularly mothers and mother-in-laws are regarded almost like law since they only want the best thing for their children and future grandchildren. People believe that it has been passed from one generation to another that pregnant women who get urut do not get any troubles. Trouble during labor is never associated with such practice. Urut is taken as a good practice; hence it will never bring any harm for pregnant women. Instead, people consider troubles during childbirth are caused by hex or in local term, ru'u.

$R u$ ' $u$ is what Detusoko people believe to be a kind of black magic used as a revenge for suspicion or conflicts (suanggi) between two peoples or more. As people of Detusoko have a strong belief in their tradition, they also believe that $r u$ ' $u$ can happen, and it can also be prevented. Since they have strong belief in such black magic, whenever something bad happens people will almost automatically turn to ru'u. So, when a pregnant woman faces troubles during labor, people tend to think that the cause is $r u$ ' $u$. People think they must have good manner, not only to their family members, but also to their social environment. It is 
commonly perceived if something bad happens to somebody who has a conflict with other people, the cause is always ru'u. Pregnant woman is an easy target since people believe that $r u^{\prime} u$ can easily aim at people who is weak mentally and physically. Although it is hard to find out who send this black magic, people generally think that $r u^{\prime} u$ will cause harms to pregnant women. Pregnant women can have difficulties during labor not because of getting urut, but because of ru'u. Oftentimes, people also believe that $r u^{\prime} u$ can cause death to pregnant women.

Older women always suggest their children or daughter-in-laws to go to TBAs to get massaged whenever they feel uncomfortable with their pregnancy. It is not uncommon for older women to invite TBAs to their houses or to take their pregnant daughters to TBAs place. People of Detusoko is governed by a patrilineal and patrilocal kinship-related tradition which dictates young couple to live together with one of the parents (usually the husband's parents). This is mostly the reason why in-laws intervene in almost every aspect of a new married couple's life. Thus, it is difficult for younger women to refuse their mother-in-laws' suggestion with regards to pregnancy-related practices, including getting massaged.

\subsection{The Role of Traditional Birth Attendants}

Data from Detusoko PHC shows there is only one trained TBA in Detusoko Village. Nevertheless, authors found several other TBAs who still help pregnant women by massaging them. These TBAs are not involved in helping labor as they are too old and some have difficulties with their eyesight. One TBA (S, 52 years old) was found to be still helping labor until $30^{\text {th }}$ June 2013 since the patient's family had already picked her up at home. S provided many information about massaging tradition amongst pregnant women. For her, and many other TBAs, it is important to help safely. Afterwards, she usually reports to primary health center so that midwives can come to give the patient an injection and to weigh the newly-born baby.

There has been a partnership between midwives and TBAs. In this partnership, TBAs' role is to take and accompany pregnant women to primary health center for labor. Nevertheless, TBAs tend to still assist pregnant women in labor especially if patient's family picks TBAs up from their home. There are many factors to explain the reasons people still choose TBAs, instead of midwives. The factors are as followed:

There is relatively higher trust towards TBAs than towards midwives. In general, midwives are younger; hence lack the experiences that people believe TBAs have. In addition, since most TBAs are older, people have known them for years. This relationship helps people to put more trust in TBAs as they witness or experience directly the help of TBAs. Generally, midwives do not have the same ability to massage pregnant women. Getting urut in Detusoko is almost inseparable from pregnant women whenever they feel tired or uncomfortable with their pregnancy. It is very difficult to change this tradition. It is also related to pregnant women's working pattern in the farm despite their condition. Furthermore, such working pattern causes infant's position to change. Getting urut is considered the only solution to this. Their energy will get recharged, while the infant is repositioned to where it is supposed to be in the mother's womb.

There are many cases of successful childbirth assisted by TBAs. Death caused by childbirth assisted by TBAs will result in the decreasing trust of people towards the TBAs. Interviews with three former TBAs and one active TBA showed that they had never had any experiences of death patients. Oftentimes, TBAs are proud for helping the labor of twin babies where both babies and mother are safe. Local people trust TBAs to be able to help any kind of conditions during labor. They also like the facts that TBAs use prayers whilst doing their job. This prayer is usually read before starting labor.

TBAs are able to help difficult labor caused by hex (ru'u). As aforementioned, people in Detusoko believe that difficult labor is caused by hex sent by other people. TBAs recognize this, although they are not able to tell who send the hex. Nevertheless, TBAs are able to relieve the influences of black magic through their prayers.

TBAs has shown on numerous cases that they are able to correctly guess the sex of newly-born babies. They are able to do this since the beginning of pregnancy. There are various ways to do this according to TBAs. Some look at the mothers' face. If the face looks clean, bright and presentable, the mothers will usually have daughters. On the other hand, if the face looks older, they will usually have sons. Another way to do it is by looking at the shape of mothers' stomach. If it stands to the right, it will usually be male babies, and vice versa.

TBAs usually do not set a standardized cost for their services. If the patients are still considered a relative, they usually do not need to pay. Sometimes, patients do not give anything much except things such as poultry, rice, and cloth as a way of expressing gratitude in tradition way. TBAs are often a neighbor or a relative. This bond eliminates the reluctance of getting their helps in labor. Even for those women who gets assisted by a male TBA, they do not feel shy despite the gender difference. It is more important to get helps from TBAs during labor, despite whatever sex the TBAs have, because delays in such cases can result in death. Relatives and neighbors who succeed in helping labor are considered like a life-savior. People tend to feel uncomfortable for the distance between them and the health workers in primary health center; hence they 
feel reluctant to get help from them during labor. On the other hand, such distance is non-existence as they interact with TBAs on daily matters.

The strong influence and dominance that TBAs have over Detusoko people has earned them respects from people of various background in Detusoko. Their words are taken as if they are laws. People must obey them. The influence of TBAs cannot be replaced by other people including interventions from health workers employed by the government. Modern medical practices applied by doctors, nurses and midwives are out of consideration for a lot of people in Detusoko. Such power relation has implicated in the central role of TBA in people's lives. People prefers going to TBAs to get examined or to help them with labor. Ban from the government via the primary health center as part of Revolution of Maternal and Infant Health program has yet to be successful. The government expects all women to get their medical check and to get assisted in their labor only in medical facility such as primary health center. However, many people still prefer TBAs for their cheap and uncomplicated services.

\subsection{Health-Related Decision Making Pattern on Family Level}

One of the causes of 2013 cases of maternal mortality in Detusoko District is delayed referral due to geographic and natural condition. In one case, a woman was already in bad condition when transferred to regional hospital in Ende. However, the car travelled through four landslides. It was practically very hard to go through. Maintenance needs more time. What made it worse was it was the only way to Ende; hence the car had to stay in queue with many other vehicles. Eventually, the patient died during the trip to the regional hospital.

The lack of education amongst people of Detusoko who are mostly elementary school graduates results in their low income. They depend largely on agricultural; however, the income from working in farms can only be used for subsistence. Consequently, health cost is not prioritized; hence it will be an additional burden if a family member has to get hospital treatment. Although free birth delivery for all (Jampersal) program has already helped to remove labor cost and antenatal care (ANC), people will still need to pay the cost of transportation of a return trip to Ende. They will also have to deal with other costs such as: living cost during their stay in Ende. It is already a custom in Ende when a family member gives birth, all members of the extended family will go to the hospital. They all eat, sleep and wash in the hospital whilst accompanying the sick. Thus, hospital referral becomes a nightmare for local people. The furthest they can hope when a member of family gives birth is the PHC since it can be reached by rented-motorbike or other public transportation. On the other hand, if a family member is referred to the regional hospital, people can already imagine the high cost incurred. Renting a car from Detusoko to Ende already costs highly since the average income in Detusoko is 1,000,000 rupiahs per month with an average of three to five children per family. Thus, it is expected that they will need to cover a large sum of money if a family member is referred to the regional hospital to cover for the living costs of every family member and the transportation costs.

The high number of pregnancy per productive woman causes the small distance between one pregnancy with another. The many number of children one has and the relatively close age-gap between one child with another makes women reluctant to have medical checked. As a result, many are reluctant to get ANC. A midwife called $\mathrm{E}$ who is 31 year-old confirmed this:

"People here (pregnant women) often are reluctant to get treated for ANC since they are ashamed of having too many children with too close an age-gap. Even some of them only get one ANC during their pregnancy. Others have no ANC at all. Since, we have no idea about their medical records; we can only do as much as referring them to the regional hospital of Ende".

In some cases, mothers have their babies aborted although they admit of miscarriage. The general repugnance of family planning program has resulted in high number of pregnancies with close gap. Local people also consider the many number of children equal to a lot of fortunes. They also believe that God will help them to provide for their children in such case. This socio-cultural factor makes it difficult for family planning program to be successful in Ende. In addition, strong cultural factor with regards to the way people make decision delays the referral.

The position of women in developing countries is lower than men. They never have their own decision making related to the body, economic, property, and authority [20]. Decision-making process amongst people of Detusoko always involves parents, parent-in-laws and other elder member of the family. This includes decision-making process related to how and where a female member of the family is supposed to give birth. The mother-to-be and her husband is not involved in such process. The decision is determined by a meeting between members of the family from the husband line. However, ironically, such meeting usually involves large number of the family who resides in different location. This only makes it difficult and 
longer to get a decision. Thus, it can also have bad implication for the mothers especially if they need immediate intervention. In several cases, such decision-making process only result in the death of the mothers. This dominant extended family makes it hard for unclear family to do anything.

\subsection{Myths about Pregnancy}

As previously mentioned, pregnancy is considered a natural occurrence for women in Detusoko. Children are what God entrusted to people. For this reason, pregnancy is not made as a priority that should be treated carefully. Pregnant women have similar diet pattern with other people. Even when they do not have appetite, they tend to not eat the whole day despite working hard in the farm. As they hold dearly to custom and tradition, people of Detusoko think it is more important to treat myths surrounded pregnancy with special care. Such myths are as followed:

a. Pregnant women are not allowed to wear accessories or other things that need to be wrap around their bodies such as: necklace, rings, bracelets as well as scarves. An exception to this is Rosario. If this rule is broken, babies will suffer from twisted cord.

b. Both pregnant women and their husband are not permitted to wrap towels around their neck when about to bath because if they do, it will affect badly on the placenta.

c. Pregnant women must not have their hair braided as it will affect badly on the placenta.

d. Pregnant women are prohibited from eating pineapples, durian, and ginger as it will result in heat which can cause miscarriage.

e. People believe that bleeding is usually caused genetically. A particular shaman is the only one that can cure this condition

f. Pregnant women are not allowed to use broken eateries since the born babies will be born with chippy lips.

g. Pregnant women and their husbands are not supposed to kill any animals as they believe the babies will be born crippled.

Myths around pregnancy are trusted more than health advises from the primary health center. People tend to disobey any health advice from any health workers such as: doctors, midwives, and nurses, despite the good intention and logics behind. On the other hand, people strongly believe in myths. As a consequence, people consider any bad incidences related to pregnancy as a result of bad behavior or waywardness towards custom rules.

\subsection{Food Taboo and Diet Pattern Among Pregnant Women}

In spite of living in fertile lands that usually harvest a variety of vegetables and fruits, diet pattern of local people do not represent this. There is a general dislike of green vegetables. People would rather eat rice slightly salted with light accompaniments such as: chilly and/or salted fish. Pregnant women have no different diet pattern with other family members who like eating rice with salt and chilly. They do not eat vegetables as they are supposed to. On the other hand, instant noodle is a popular meal for literally all people, and pregnant women are not an exception. If pregnant women have no appetite in eating rice or cassava, they will opt for instant noodle. For local community, the notion of having a meal means eating rice. Any kind of side dish is not a must. Often, pregnant women follow whatever they think the babies want. For example, if they feel nauseous, they will not force themselves into eating. When they have no appetite, they will usually only eat two spoonfuls of rice, without side-dishes or they will eat only boiled bananas, boiled corn, cassava or instant noodle. Although both TBAs and midwives keep reminding pregnant women to eat nutritious food routinely, it is still difficult to change the habits of not prioritizing nutrition, whilst prioritizing hard work in the farms. In one part of the village, an untrained shaman suggested a woman not to eat too much, but to work hard since less work will make labor difficult. Food taboo for pregnant women include snacks, cold beverages, and even medicine from the primary health center. Although it should be noted that these medicines are nutrition supporter so that women will be spared from risks such as anemia. Women are also not allowed to consume sugar cane since it is believed that doing so will result in watery babies' ear.

Diet pattern of pregnant women is no different from the general population. They eat whatever is available. They never prioritize nutrition for pregnant women. Furthermore, there various other practices that a pregnant woman should do such as getting ANC, giving birth in medical facilities, not getting massagedwhich people of Detusoko pay no attention to. Doctors, midwives, and health cadres has often socialized the importance of maternal health, but old customs are not that easy to be transformed. A 48-year old midwife (L) who had been doing her job in the village for over 23 years said that she felt like a failure in bringing positive change in Detusoko. The lack of human resource as a result of limited education and the influence of extended family in decision-making process have all been too difficult to change. As L said: 
"I've been working here for over 23 years as a midwife. However, there are still too many practices pregnant women do that are difficult to get rid of. I felt as failure. I felt I have failed helping them to get better. Poverty, limited human resources, and tradition are too powerful here."

Although there are only few numbers of food taboo, the effect is significant for pregnant women's diet pattern. Pregnant women and Detusoko people prefer salted fish to vegetables. Therefore, food taboo in this case vegetable - will only decrease people's interest in vegetable even lower. Besides, vegetable is considered as not tasty as what they consider delicious consists of merely rice, salt and chili. For them, having a meal is eating rice only. This kind of pattern is also held by pregnant women. Banana and cassava are considered as alternative to rice. So, whenever they do not feel like eating rice, they will only have banana and cassava as a replacement.

\subsection{The Meaning of Maternal and Infant Mortality in Gender-relation}

Death is a part of life cycle like being born, growing older, and getting old. In relation to death, every individual will experience different kind of death. Maternal and infant mortality in a community with a relatively high rate of maternal and infant mortality like Ende should mean something for them. The death of pregnant women or newly-born babies is often regarded as 'sudden death'. The reason is they never expect that death will come that soon since it involves no sickness. Death is not in one's imagination with regards to pregnant women since they only hope for a healthy mother and child. Maternal and infant mortality is treated as a very sudden occurrence that no one in the family dream of. It often becomes a bitter pill that people have to swallow. Nevertheless, they consider it as part of God's plan, hence, moving on is only rational.

From many cases of maternal and infant mortality in Detusoko, every family member admitted the loss and regret. Some questioned why it was the mother and/or the baby who died, and why not other family member such as the head of the family. The memory about the mother and the baby cannot be erased easily. The huge loss is felt by family members. Thus, any death of a mother and/or a baby will be dealt with a lot of tears and sadness.

Basically, death has an almost similar meaning for every religion. Most people of Detusoko are Catholics. They also have similar interpretation of death. They will mourn the loss of any member of the family, including elderly and pregnant women and/or babies. Infant mortality, in particular, should not be treated with great regret since people believe that those babies will be born again as fairies who live in the heaven and will make both parents happy. Maternal and infant mortality are treated similarly with other deaths since both mothers and babies die as intact human. They will be treated and buried in the same way as other people. It means the ceremony will be held in accordance to Catholic religion and tradition. In Catholic, especially if the dead is already baptized, the ceremony is led by a priest. This includes babies as long as they are baptized already. Their ceremony will be held like an adult. The prayers and ceremonial ritual will be conducted by a priest and his people. According to $\mathrm{P}$, a nun in the local church, in Catholic teachings, dead infants will turn into fairies or angels. They will save the parents, especially the mothers.

\subsection{Cultural Transformation as an Effort to Decrease Maternal and Infant Mortality Rate}

Based on the findings classified in four topics, the next stage determines the formulation of cultural transformation that will be useful to decrease maternal and infant mortality rate. In principle, transformation here aims at maintaining health-related local wisdoms. It is done by transforming local behavior pattern into behaviors that are beneficial for public health in general and maternal health in particular without eliminating their local tradition. In other words, outer appearance remains the same, only the content is altered.

1. Massaging tradition amongst pregnant women is changed into urut on the upper part of the body as pregnant women usually suffer from back pain. This massage is targeted to the upper part of the body; hence will not bring harm to the stomach area. This can be practiced from the first three months until labor 2.Spa for the pregnant women. TBAs will be suggested to change their massaging practice which will focus more on the upper part of the body. Therefore, it is expected that they will not do any urut to pregnant women in the future 3.Looking at the actual involvement of TBAs in helping labor, TBAs will be advised to stop their practices by doing other tasks related to labor. Although many of them are not even graduates of 9year primary education, they will be taught to be health cadre in Integrated Health Service (Posyandu). Their tasks include mentoring and motivating pregnant women to give birth in health facilities. By doing this, TBAs will get rewards. They will still be permitted to do urut only on the upper parts of the body. Therefore, they will not lose any income. Their role is decreased, but not eliminated. Their existence and merit are not erased, but only altered 4.TBAs will be encouraged to be motivator for pregnant women so that pregnant women give up their food taboo and start eating nutritious food 5.TBAs, community leaders, government 
officials, and religious leaders are involved in the campaign of health lifestyle for pregnant women. The campaign will also aim at renouncing unhealthy local practices. Maternal health will be prioritized in order to make the prevention of maternal and infant mortality a public matter 6.Schools and churches will be activated as the forefront of reproductive health campaign for youths. Teenagers will be introduced to reproductive health matters since they are young. Therefore, they will be able to prevent themselves from suffering harmful conditions such as anemia, malnutrition, and food taboo 7.Informal schooling or female schools need to be introduced so that women will have more knowledge on nutrition 8.It is important to increase family awareness of maternal and infant health by improving men's role in decision-making process at family level. The role of extended family is transferred into education-related decision-making. Maternal and infant health should be made priority in the family. Human resource including family's economy should be improved. Thus, the next generation will no longer suffer from malnutrition among children and anemia among pregnant women 9. The myth that pregnant women should always work hard to get smooth labor must be abandoned. Transformation can be done by prohibiting pregnant women from working too hard so that they will not feel exhausted and other uncomfortable feelings.

Fatalistic way of thinking has been the base of Detusoko life. Hope and fate are entrusted to God. They believe that God will help human in every life difficulties. Consequently, human do less work, and only rely on the universe. Efforts in life advancement including attempts to prevent illness are not common in Detusoko public life.

Commonly, the cause of illness in Detusoko is based on magico-religious model and holistic model, rather than biomedical model [11]. As a result, all illness diagnosed by health workers is countered. People believe all illness is a result of black magic. Bleeding, twisted cord and even maternal and infant mortality is regarded as not related to minimal treatment during pregnancy such as: massaging habit, malnutrition, and lack of ANC. They consider everything as a result of ru'u.

The tradition of $u r u t$ is difficult to be eliminated for its psychological aspects. The heavy workload a pregnant woman has is the reason she often feels tired. Massage is the easy solution to such condition. The conflicts are still apparent between health-related tradition such as food taboo, massaging, getting assisted by TBAs during labor, as well as the belief of nijo and modern health behavior such as eating nutritious food, leaving massage, labor in health facility, and trust in modern medical cure and treatment. The person of Detusoko is still dominated by metaphysics way of thinking. The cause of personalistic disease such as black magic is still stronger than naturalistic cause of illness [11],[21],[22]. The characteristic of traditional community is emphasized for communality way of life, old way of thinking, limited knowledge and education. Detusoko is a part of Southeast Asia which diversity of geography and history, including social, cultural and economic differences, has contributed to highly divergent health status and health system across and within countries [23]. However, it is obvious that changing local custom and tradition will engender conflicts. Cultural transformation will be the best choice considering local culture is not eliminated, but only altered slightly in terms of its use, time, and methods. By doing so, it is hoped that behavior change will be more successful than merely introducing modern medical methods which only result in public antipathy towards the health authorities.

\section{CONCLUSION}

The cause of maternal mortality such as extended family involvement in decision-making process, diet pattern during pregnancy, anemia, food taboo, individual treatments during pregnancy including getting massaged, heavy workload during pregnancy, and the strong belief of black magic has made TBAs role stronger in the community.

On the other hand, the cause of maternal mortality is also related to the condition of the mothers, low trust in health authorities especially primary health center that often gives referral to regional hospital, the understanding of infant's sickness as normal sickness, as well as people's belief that death signs spread all over the living area which makes it not surprising anymore for people around if a mother and/or infant die. Even though maternal and infant mortality is treated as sudden death, no family members expect this as seen from many cases of loss, despair, and disappointment for death that happened a long time ago.

Cultural transformation is considered as the best option for Detusoko people so that local customs are not eliminated, but only altered. Massage for pregnant women will be altered into massage to relieve back pain only on the back of pregnant women. Thus, it eliminates massage on the belly. The role of TBAs is targeted to be health cadre in the fourth desk of Posyandu so that they can encourage pregnant women to have modern medical treatment. However, TBAs can still help by massaging the back. The efforts to involve as many stakeholders as possible such as local government, tradition and religious leaders as well as education institution are meant to socialize healthy lifestyle for young people. The expected outcome is they

IJPHS Vol. 5, No. 1, March 2016:84-93 
will get accustomed to healthy lifestyle since they are young. Thus, they will have healthy pregnancy and safe labor.

\section{ACKNOWLEDGEMENTS}

This research is funded by Faculty of Cultural Sciences, Universitas Gadjah Mada, Yogyakarta. The author would also like to express her gratitude to Australian Indonesian Partnership Maternal and Neonatal Health (AIPMNH), Health Department at Ende Regency, as well as Ende local government for their supports and help in accessing Detusoko local community. The author would also sincerely thank the people of Detusoko, the staffs of PHC, government officials, and susteran Detusoko who have been a great host for the research team.

\section{REFERENCES}

[1] Biro Pusat Statistik-BKKBN-Depkes-Macro International, "Survei Demografi dan Kesehatan 2007”, Jakarta, BPS, 2008.

[2] Biro Pusat Statistik, "Sensus Penduduk 2010”, Jakarta, BPS, 2010.

[3] AIPMNH, "Inisiatif Dari Kabupaten", Kupang, Australia Indonesia Partnership for Maternal and Neonatal Health 2013.

[4] www.mutu.kia.ntt, accesed April 13, 2013.

[5] Biro Pusat Statistik, Penduduk Provinsi Nusa Tenggara Timur, "Hasil Survei Penduduk Antar Sensus 2005", 2005.

[6] SDKI, "Indonesia Demographic and Health Survey 2007", Calverton, Maryland, USA, BPS and Macro International, pp. 102, 2007.

[7] Counihan, CM., "The Anthropology of Food and Body, Gender, Meaning and Power", New York, Routledge, 1999.

[8] Sanyoto, WK., "Praktek Aneka Penyembuhan, Pijat, Kerikan, Gosokan”, Pekalongan, CV Bahagia, pp. $25,1995$.

[9] Intisari, "Pengobatan Alternatif", Jakarta, Intisari Mediatama, 2004.

[10] Sciortino, R., "Menuju Kesehatan Madani”, Yogyakarta, Pustaka Pelajar, pp. 72, 1999.

[11] Galanti, AG., "Caring for Patients from Different Culture”, Philadelphia, University of Pennsynlvania Press, 2008.

[12] Hull, V., "Women, doctors, and family health care: some lessons from rural Java", Studies in Family Planning, vol. 10, pp. 315-325, 1979.

[13] Ahimsa-Putra, HS., "Bahasa, Sastra dan Kearifan Lokal di Indonesia", Seminar Nasional Bahasa Indonesia dan Bahasa Daerah Dalam Konteks Keindonesiaan II, Kantor Bahasa Propinsi NTB, 2009.

[14] Fernandez, SO., "Kebijakan Manusia Nusa Tenggara Timur Dulu dan Kini”, Ledalero, Sekolah Tinggi Filsafat Katholik, 1991.

[15] Sharma, BV., Majhi, J., "Child Birth and The Role of traditional Birth Attendants Among The Savara and Jatapa Communities Andhra Pradesh", Indian Anthropologist, vol/issue: 37(2), pp. 55-69, 2007.

[16] Becroft, D., Gunn, T., "Prenatal Cranial Hemorrhages in 47 Pacific Islander infants: is traditional massage the cause?", The New Zealand Medical Journal, vol/issue: 102(867), pp. 207, 1989.

[17] Abrahams, N., Jewkes, R., Mvo, Z., "Indigenious Healing Practices and Self-Medication amongst pregnant women in Cape Town, South Africa", African Journal of Reproductive Health, vol/issue: 6(2), pp. 79-86.

[18] Fronczak, N., Arifeen, SE., Moran, AC., et.al, "Delivery practices of traditional birth attendants in Dhaka slums, Bangladesh", Journal of Health, Population and Nutrition, vol/issue: 25(4), pp. 479-487, 2007.

[19] Phillipson, M., "Phenomenological Philosophy and Sociology in Filmer (eds.)", New Direction in Sociology Theory, London, Collier MacMilan.

[20] Burns, AA., Lovich, R., Maxwell J., Shapiro, K., "Pemberdayaan Wanita dalam Bidang Kesehatan", Yogyakarta, Yayasan Essentia Medica, pp. 24, 2000.

[21] Hardon, A., Boonmongkol, P., Streeland, P., et.al., "Applied Health Research Manual, Anthropology of Health and Health Care", Den Haag, Cip Data Koninklijke Bibliotheek, pp. 21, 1995.

[22] Foster, GM., Anderson, BG., "Medical Anthropology", London, John Wiley and Sons, Inc, 1978.

[23] Chongsuvivatwong, V., Phua, KH., Yap, MT., Pocock, NS., Hashim, JH., Chem, R., Wilopo, SA., Lopez AD., "Health and Health- Care System in Southeast Asia: Diversity and Transitions", The Lancet, pp. 1, 2011. 